\title{
DEBATE: Réplica
}

\section{Comentários a partir da entrevista de Hélgio Trindade}

\author{
Comentarios de la entrevista de Hélgio Trindade \\ Comments on the interview with Hélgio Trindade
}

Alexandre Pinheiro Ramos*

A edição mais recente da revista Estudos Ibero-Americanos (volume 42, número 1, 2016) trouxe uma valiosa entrevista com Hélgio Trindade feita por René E. Gertz, Leandro Pereira Gonçalves e Vinícius Liebel, a qual gira em torno, sobretudo, da temática da Ação Integralista Brasileira, marcando assim os 45 anos da tese de Trindade, incontornável obra clássica sobre o assunto - entrevista esta, ressalte-se, precedida por uma irretocável introdução sobre o entrevistado. Também pesquisei a AIB e em 2014 publiquei um artigo em lembrança pelos 40 anos da publicação do livro Integralismo: o fascismo brasileiro na década de 1930 na revista Antíteses (cf. RAMOS, 2014). Fui ler assim a entrevista e, para minha surpresa, vi os breves comentários feitos por Hélgio Trindade ao meu trabalho.

Lembro-me que após a publicação daquele artigo, entrei em contato por e-mail com Hélgio Trindade para lhe enviar o artigo que era a minha maneira, talvez pouco ortodoxa, de homenageá-lo pela ocasião; em seguida, também enviei minha tese de doutorado, defendida em 2013 (RAMOS, 2013) - acredito que a proximidade dos eventos tenha, em parte, motivado a menção de Hélgio Trindade. Foi, assim, com satisfação que vi meu trabalho mencionado junto de tantos outros que compõem a bibliografia sobre o Integralismo. E parte de minha satisfação

* Doutor em Sociologia. <alexandre1337@yahoo.com.br><dados biográficos/biographic data> 
deveu-se ao tom crítico de suas considerações, pois vejo no exercício da crítica não só um elemento crucial para o desenvolvimento e progresso do conhecimento, como também a possibilidade de se entabular um diálogo. Gostaria, assim, de fazer dois comentários a partir do que foi dito por Hélgio Trindade.

Sobre a análise da recepção de sua obra, presente em minha tese (2013) e expandida no artigo de 2014, reconheço que faltou uma explicação sobre o uso da expressão "objeto sagrado" (RAMOS, 2014, p. 343), o que, acredito, contribuiu para a crítica de Trindade. Tal alusão ao "sagrado" (presente, se não estou enganado, apenas no artigo) veio da obra de Randall Collins, The Sociology of Philosophies (1998), na qual seu autor refere-se a livros, ideias, teorias que possuem grande valor para determinados grupos de intelectuais como "objetos sagrados". Mas independentemente desta omissão, não vejo paradoxo em minha crítica, pois seu alvo não foi a obra e seu conteúdo, mas sim, durante o processo de recepção, o modo como os pesquisadores do integralismo se relacionaram com ela e, também, seus efeitos nos estudos sobre a AIB. Em momento algum pretendi afirmar a perda do caráter científico da tese de Trindade (tampouco que a ampla aceitação de qualquer outra leve a tal perda!). Muito pelo contrário: a meu ver, devido ao modo como a tese foi recebida e mobilizada, acredito que se impuseram limites à investigação, incorrendo inclusive na perda de parte do potencial heurístico da obra e dos diversos questionamentos que ela suscita (note-se que não pretendo generalizar esta crítica para todas as pesquisas).

Quando reconheço a grande recepção positiva da tese de Trindade, atribuo-a, principalmente, à capacidade explicativa de seu conteúdo discordo de abordagens observadas no campo da história e sociologia da ciência que consideram os produtos científicos apenas o resultado de consensos e escolhas baseadas em interesses, reduzindo seu conteúdo a mero epifenômeno da vida social e sem qualquer autonomia e lógica próprias. Mas isto não significa dizer que não haja problemas advindos desta ampla aceitação. E na tese e no artigo mencionados acima procurei argumentar nesta direção, acerca da recepção e seus efeitos. Ao mesmo tempo em que a obra de Trindade viabilizou uma série de pesquisas com enfoques e abordagens distintas, a maneira como foi recepcionada levou também a uma série de restrições que apontei ao longo do artigo.

Sobre a crítica de Hélgio Trindade à minha tese, sublinho um pequeno equívoco atribuído à hipótese central, pois não asseverei ou 
busquei demonstrar uma "natureza eminentemente intelectual da AIB" - o problema aqui está no eminentemente. Tanto na redação da tese quanto, mais tarde, na passagem desta para a forma de livro (RAMOS, 2015) procurei evitar uma supervalorização da dimensão intelectual ao ponto de se sobrepor a outras:

[não] pretendi lançar sobre os intelectuais integralistas toda a responsabilidade pelo desenvolvimento da AIB, bem como pelas características que assumiu ao longo dos anos. Minha intenção foi compreender e refletir sobre a participação destes agentes no movimento, concluindo que eles cumpriram um papel decisivo sobre sua organização - porém, não foram os únicos (RAMOS, 2013, p. 326; 2015, p. 267).

Talvez me tenha faltado uma maior qualificação do que pretendia dizer com "intelectual", indicando não haver na produção integralista grandes reflexões ou formulações comparáveis a outras que compunham o contexto intelectual brasileiro na época. Mas o que mais me interessava eram as atividades e práticas intelectuais presentes no início do movimento e que persistiram até seu fim; era o recurso constante (e crescente) a bens culturais variados na transmissão e cotidianização das ideias integralistas; era a presença de pessoas identificadas com, ou que se dedicaram a atividades intelectuais - e como tudo isto se articulou no interior do movimento e contribuiu para seu desenvolvimento e expansão. Que toda a produção intelectual integralista possuía uma dimensão instrumental, voltando-se (também) para o proselitismo e recrutamento de adeptos, isto não se pode negar. Mas considerá-la unicamente na chave da instrumentalização é perder de vista o complexo de valores, crenças e subjetividades envolvidas e com o qual os intelectuais da AIB e seu público se relacionaram - e que contribuiu para a "popularidade" do integralismo. Aliás, como busquei demonstrar, a própria questão do carisma vincula-se ao trabalho e práticas intelectuais verificadas no interior da AIB. Neste sentido, a hipótese de minha tese não diz respeito a uma "natureza intelectual" do movimento integralista, mas sim que práticas identificadas com o microcosmo intelectual foram cruciais para seu desenvolvimento. E mesmo que restringisse minha avaliação da produção integralista à sua dimensão instrumental, ainda assim ela não seria incompatível com as atividades intelectuais. Embora não tenha explorado como poderia essa questão em particular, minha análise buscava levar em consideração a dimensão axiológica, os valores que informavam as ações e eram transmitidos pelos vários bens simbólicos 
produzidos pela máquina integralista, não se esgotando nas contendas políticas. Deste modo, se há problemas em minha hipótese e em sua demonstração, a meu ver não estão onde indicado por Hélgio Trindade.

Pode parecer exagero redigir algo em torno de três páginas para responder dois parágrafos, mas é a maneira que tenho à mão para demonstrar minha valorização do intercâmbio crítico e, principalmente, agradecer pelos comentários críticos e pela possibilidade de estabelecer um diálogo, mesmo que breve, sobre um tema ao qual as partes envolvidas dedicaram não só suas reflexões, mas também alguns anos de suas vidas. Agora, ainda que minhas pesquisas tenham seguido outros rumos - coincidentemente, lidam com outro tema também trabalhado por Hélgio Trindade, que é a história das ciências sociais - aguardarei pelo seu novo livro.

E se, de algum modo, como Hélgio Trindade diz na entrevista, o tópico em minha tese sobre a recepção de sua obra instigou-o a voltar ao tema do integralismo (TRINDADE, 2016, p. 205), isto só reforça minha predileção pela crítica como elemento central do ambiente intelectual. Deixo aqui registrado meus agradecimentos ao grande pesquisador e estendo-os a revista Estudos Ibero-Americanos que gentilmente cedeu espaço para a publicação desta resposta.

\section{Referências}

COLLINS, Randall. The sociology of philosophies: a global theory of intellectual change. Cambridge, Massachusetts, London: The Belknap Press of Harvard University Press, 1998.

GERTZ, René E.; GONÇALVES, Leandro Pereira; LIEBEL, Vinícius. Camisas Verdes, 45 anos depois - uma entrevista com Hélgio Trindade. Estudos Ibero-americanos, Porto Alegre, v. 42, n. 1, p. 189-208, abr. 2016.

RAMOS, Alexandre Pinheiro. Intelectuais e Carisma: a Ação Integralista Brasileira na década de 1930. 2013. Tese (Doutorado em Sociologia) - Instituto de Filosofia e Ciências Sociais, Universidade Federal do Rio de Janeiro (UFRJ), Rio de Janeiro, 2013.

Intelectuais, carisma e Ação Integralista Brasileira. Rio de Janeiro: Editora Garamond, 2015.

. O "Integralismo" de Hélgio Trindade quarenta anos depois: uma reflexão crítica sobre sua recepção. Antíteses, Londrina, v. 7, n. 14, p. 324-347, dez. 2014.

\section{Autor/Author:}

ALEXANDRe Pinheiro RAmos <alexandre1337@yahoo.com.br>

- Pós-doutorando (CAPES/PNPD) na Universidade Federal do Rio de Janeiro. Doutor em Sociologia pela Universidade Federal do Rio de Janeiro (PPGSA/UFRJ).

- Post-doctoral fellow (Capes/PNPD) at the Universidade Federal do Rio de Janeiro (UFRJ). PhD in Sociology from the Universidade Federal do Rio de Janeiro (PPGSA/UFRJ). 